\title{
Evolution of Interpersona Communication Through Symbols (Sticker) Cyber Native in the Line App
}

\author{
Noor Aini Rachmawati ${ }^{*}$, Oryza Devi Salam², Giovani Anggasta Setiawan³, \\ Regina Geovania Anggasita Izaak ${ }^{4}$ \\ 1,2,3,4 Marketing Communication Program, Communication Department \\ Faculty of Economics \& Communication, Bina Nusantara University \\ Jakarta 11480, Indonesia \\ nooraini@binus.ac.id; oryza.salam@binus.ac.id; giovani.setiawan@binus.ac.id; \\ regina.izaak@binus.ac.id \\ *Correspondence: nooraini@binus.ac.id
}

\begin{abstract}
The essence of man in life is to conduct communication activities. An individual is said to communicate with others if both have an understanding of the meaning of the message conveyed in his interaction. Advances in information communication technology provide opportunities for individuals to more easily interact over the internet. Of the recorded internet users, 130 million are active on social media. New Media Communication, or communication based on information technology, makes social media a prima donna for individuals to interact socially in cyberspace. Text-based communication platforms such as WhatsApp and LINE make it easier for individuals or those in cyberspace referred to as digital natives to interact. These digital natives in their interactions do the continuous thing as a habit that eventually becomes a culture of communication. In this research, the focus of research is the evolution of communication between users in the new media era in LINE users as a text application-based social media with a constructivist approach, qualitative research methodology with virtual ethnographic research methods and descriptive analysis levels. Data collection with online interviews, as well as chat history observations and the use of LINE sticker features. The purpose of the study is: (1) to find out the communication of digital natives on the LINE application platform, (2) to find out the evolution of interpersona communication formed from the results of native digital interactions on the LINE application platform using a virtual ethnographic approach.
\end{abstract}

Keywords: LINE Applications; Digital Natives; New Media Era; Virtual Ethnography; Communication Evolution

\section{INTRODUCTION}

The essence of man in life is to conduct communication activities. An individual can be said to communicate if both have an understanding of the meaning of the message conveyed in his interaction. From the page www. communicationtheory.org communication theory, is a process of transferring messages in the form of thoughts, information, emotions and ideas through gestures, sounds, symbols, signs and expressions from one person to another. The three most important and essential things in any communication process are senders - senders, receivers - receivers and channels - channels. Marking that the communication process takes place if there is a message sender and a message recipient. West and Turner (2009: 5-8), "communication is the social process by which individuals use symbols to create and interpret meaning in their environment". This definition of communication indicates that communication is achieved if fulfilled five concepts of communication, namely: process, social, symbol, meaning and environment. These five concepts are described as follows: 
1. The process is something that always runs, is dynamic and will not stop. Communication has no clear beginning and end. Communication with others in the past has been stored in the individual's mind and affects the individual's communication with that other person currently or perhaps in the future.

2. Social shows that human and interaction are part of the communication process. That is, communication always involves two people, the sender and the receiver, and they play an important role in the communication process.

3. A symbol is a label given to a particular phenomenon. An example is a symbol or the word love represents an idea of love and the word chair represents an occupied object.

4. Meaning is the content and what is obtained from a message conveyed from the communicator to the communicant.

5. An environment is the situation or context in which the communication process occurs. Environmental elements include the time, place, period, past, relationships, and cultural backgrounds of the sender and receiver.

As explained earlier that an individual can be said to communicate with others if both have an understanding of the meaning of the message conveyed in his interaction. Advances in information communication technology provide opportunities for individuals to more easily interact over the internet. In 2017, the number of internet users in Indonesia reached 143.26 million people or 54.68 percent of the total population of Indonesia.

This number increased compared to the previous year, which was recorded in 2016 which reached 132.7 million people. Of the recorded numbers, 130 million are active on social media. New Media Communication, or communication based on information technology, makes social media a prima donna for individuals to interact socially in cyberspace. The meaning of social media or in English "Social Media" according to grammar consists of the word "Social" which has a social meaning or an interaction and "Media" is a container or social place itself.

Shimp and Andrews (2013: 378) in their book Advertising Promotions and Other Aspects of Integrated Marketing Communications, social media is a mobile technology that turns communication into interactive dialogue. The purpose of social media is to use social interaction and create value for others. Digital natives individual social media users, as a technologically literate generation use social media to express themselves, form groups, network and participate in an activity. One of the social media that is currently being widely used by digital natives is the LINE application - a social media based instant conversation communication platform.

In communicating through digital media, of course, it cannot be separated from the symbols that participate in the communication process in it. Therefore, it can also be seen from the aspect of symbolic communication. Communication or symbolic interaction itself according to Herbert Blumer is a human activity that exchanges symbols that have been given meaning or there is meaning in it. It represents what a person means to communicate with others, in this case the use of stickers in the LINE application. This symbolic interaction also describes the language, social interaction, and reflectivity that occurs when a person communicates, either directly or through social media.

Text-based communication platforms such as LINE are what significantly make it easier for individuals or those in cyberspace referred to as digital natives to interact. These digital natives in their interactions do the continuous thing as a habit that eventually becomes a culture of communication.

Straubahaar and Laruse (2006:20) show that there is an evolution of conception in communication in the era of conventional media and new media. The conception of communication ranging from intrapersonal to mass communication has shifted. This change is characterized by the use of media that physically evolve rapidly as information technology evolves. In this new media era, all information systems have been digitized, so that almost all communication takes place within media technology. So digital natives bring new habits in the culture of communicating.

In this study, the focus of the research is the evolution of face-to-face conventional communication between personas into a new media communication culture in LINE users as a text application-based social media, with a constructivist approach, qualitative research methodology with virtual ethnographic research methods, with descriptive analysis. 
Data collection with online and offline interviews, as well as observation of chat history and the use of whatsapp features. The purpose of the research is (1) to know the culture of digital natives communication on the LINE application platform, (2) to find out the communication culture formed from the results of digital natives interaction on the LINE application platform. As a form of findings / innovations that are expected from the research conducted is in the form of software (software) that can recognize the emotional character of the user, from the track record of symbols (emoticons) used regularly.

LINE social media in relation to distance efficiency, time and resources in the context of organizational communication obtained the results of research that the use of LINE social media is the right choice to bridge and facilitate communication in organizations that tend to require intense, urgent and fast-paced communication, especially when approaching events or organizational activities.

The fun nature of LINE is able to create an exciting communication climate so that the message conveyed tends to be an informal and more flexible message that is able to foster closeness and make the organizational climate more relaxed so as to cut the hierarchy in communication. In fact, when finding an urgent situation the organization is also able to discuss online and get satisfaction in communicating through the features contained in LINE, such as polling for voting, and so on. This proves that organiasation communication is able to switch from conventional to mediated and still run smoothly.

\section{METHODS}

The study used virtual ethnography on communication between personas on the LINE instant text platform to specifically observe the use of stickers as visual communication of images in conversations. Ethnography is typical research involving ethnographers to participate as observers, either overtly or covertly to observe what is happening in people's daily lives (Bate, 1997).

Virtual ethnography is a critical approach. Where on the critical approach of recognition comes from two parties, researchers and informants are studied. That's why virtual ethnography is resuscitating, offering and empowering. The first issue in the virtual ethnographic research debate, is about the trust and authenticity of data. The online environment is an environment that is considered hostile, impersonal (mutually unfamiliar) and the availability of valid data is small and shallow (Sharf, 1999).

\section{RESULT AND DISCUSSION}

\section{Informant Profile}

Informant said a significant part of the research needed in this study related to the discussion of research, namely the Evolution of Interpersona Communication Through Cyber Native Symbols (Stickers) In Text-Based Applications (Virtual Ethnographic Study of LINE Application Users). The data was obtained by ethnographic research methods used to describe how individuals who use their culture interpret reality.

In research with ethnographic methods aimed at describing communication between individuals with the medium of communication platform text-based communication LINE. In this research, researchers conducted observations on communications conducted by informants on the LINE text platform. Data is also dug through semi-structured interview processes and questionnaires with several informants in order to meet the needs of more complete and in-depth research data.

Key informants in this study are individual users of the LINE application, especially those categorized into generation $\mathrm{X}, \mathrm{Y}$ and $\mathrm{Z}$. Who use the LINE text application in their daily social lives. Generation $\mathrm{X}$ is a generation born in the early years of technological and information developments such as the use of PCs (Personal Computers), video games, cable TV and the internet.

Generation $\mathrm{Y}$ is known as the mellenial generation or millennials. Generation $\mathrm{Y}$ uses many instant communication technologies such as email, SMS, instant messaging and others. This is because generation $\mathrm{Y}$ is a generation that grew up in the internet boom era, while Generation $\mathrm{Z}$ is the youngest generation that has just 
entered the workforce. This generation is usually called the internet generation Atai Igeneration. Generation Z has more social connection through cyberspace. Since childhood, this generation has been widely introduced by technology and is very familiar with smartphones and categorized as a creative generation.

Here are the categories of generational divisions according to the period of birth:

Menurut Kupperschmidt (2000) (dalam Putra, 2016) Generasi adalah sekelompok orang yang memiliki kesamaan tahun lahir, umur, lokasi dan juga pengalaman historis atau kejadian-kejadian dalam individu tersebut yang sama yang memiliki pengaruh seignifikan dalam fase pertumbuhan mereka. Jadi, dapat dikatakan pula bahwa generasi adalah sekelompok individu yang mengalami peristiwa - peristiwa yang sama dalam kurun waktu yang sama pula.

\begin{tabular}{|c|c|c|}
\hline Generasi X & Generasi Y & Generasi Z \\
\hline Born between 19 & Born between 1980 - 1995 & Born between 1995 - 2010 \\
\hline $\begin{array}{l}\text { Generasi } X \text { adalah generasi } \\
\text { yang lahir pada tahun-tahun } \\
\text { awal dari perkembangan } \\
\text { teknologi dan informasi } \\
\text { seperti penggunaan PC } \\
\text { (personal Computer), video } \\
\text { games, TV kabel dan internet. } \\
\text { Generasi X ini mampu } \\
\text { beradaptasi dan mampu } \\
\text { menerima perubahan dengan } \\
\text { cukup baik sehingga dapat } \\
\text { dikatakan sebagai generasi } \\
\text { yang tanggung, yang memiliki } \\
\text { karakter. }\end{array}$ & $\begin{array}{l}\text { Generasi Y dikenal dengan } \\
\text { sebutan generasi mellenial atau } \\
\text { milenium. Generasi Y ini banyak } \\
\text { menggunakan teknologi } \\
\text { komunikasi instant seperti email, } \\
\text { SMS, instant messanging dan } \\
\text { lain2. Hal ini dikarenakan generasi } \\
\text { Y merupakan generasi yang } \\
\text { tumbuh pada era internet } \\
\text { booming (Lyons, 2004) (dalam } \\
\text { Putra, 2016). Tidak hanya itu saja, } \\
\text { generasi Y ini lebih terbuka dalam } \\
\text { pandangan politik dan ekonomi, } \\
\text { sehingga mereka terlihat sangat } \\
\text { reaktif terhadap perubahan } \\
\text { lingkungan yang terjadi di } \\
\text { sekelilingnya. } \\
\text { Ciri/Karakteristik: Lebih } \\
\text { berkomitmen terhadap } \\
\text { team orientation fokusnya. } \\
\text { Menyukai feedback dan juga suka } \\
\text { perusahaan, pekerjaan merupakah } \\
\text { salah satu prioritas, tapi bukan } \\
\text { prioritas utama, menyukai }\end{array}$ & $\begin{array}{c}\text { Generasi Z merupakan } \\
\text { generasi yang paling muda } \\
\text { yang baru memasuki } \\
\text { angkatan kerja. Generasi ini } \\
\text { biasanya disebut dengan } \\
\text { generasi internet atai } \\
\text { Igeneration. Generasi Z lebih } \\
\text { banyak berhubungan sosial } \\
\text { lewat dunia maya. Sejak } \\
\text { kecil, generasi ini sudah } \\
\text { banyak dikenalkan oleh } \\
\text { teknologi dan sangat akrab } \\
\text { dengan smartphone dan } \\
\text { dikategorikan sebagai } \\
\text { generasi yang kreatif. } \\
\text { Ciri/Karakteristik: Lebih } \\
\text { menyukai kegiatan sosial } \\
\text { dibandingkan generasi } \\
\text { sebelumnya, lebih suka di } \\
\text { perusahaan start up, multi } \\
\text { tasking, sangat menyukai } \\
\text { teknologi dan ahli dalam } \\
\text { mengoperasikan teknologi } \\
\text { tersebut, peduli terhadap } \\
\text { lingkungan, mudah } \\
\text { terpengaruh terhadap } \\
\text { lingkungan mengenai produk }\end{array}$ \\
\hline
\end{tabular}

Figure 1. Generation Categorization Images: Characteristic X,Y, Z By Year of Birth

(Source: https://parent.binus.ac.id/) 
positif dan menyukai

kebebasan dan punya ruang untuk berkembang. tantangan baru yang menantang

yang membuat diri mereka harus pushed their limits. ataupun merek2, pintar dan

mudah untuk menangkap informasi secara cepat.

Perbedaan karakteristik yang paling signifikan antara generasi $X, Y$ dan $Z$ adalah penguasaan informasi dan teknologi. Bagi generasi $Z$, informasi dan teknologi adalah hal yang sudah menjadi bagian dari kehidupan mereka, karena mereka lahir dimana akses terhadap internet sudah menjadi budaya global, sehingga berpengaruh terhadap nilai dan pandangan tujuan hidup mereka. Pada tahun ini, rata-rata di dunia pendidikan, generasi yang paling banyak sedang menempuh jenjang perkuliahan adalah generasi milenial. Dimana generasi milenial biasanya menyukai sesuatu yang out of the box, sangat suka tantangan dan penghargaan. Mereka cenderung overconfidence, berani mengungkapkan pendapat, baik langsung ataupun lewat media sosial. Generasi ini (milenial) tumbuh seiring dengan munculnya berbagai terobosan baru dalam teknologi komunikasi, dari mulai SMS, $E$ mail, aplikasi Instant Messaging seperti BBM, Whatsapp, Line, dan berbagai bentuk komunikasi tertulis lainnya. Bentuk komunikasi tertulis dirasa lebih nyaman dan tepat oleh generasi milenial. Generasi milenial juga cenderung menciptakan lingkungan kuliah, kerja dan percakapan sehari-hari yang tidak terlalu formal. Hal ini menunjukkan bahwa milenial lebih menyukai semua bentuk komunikasi yang lebih bersahabat dan nada bicara yang lebih akrab.

\begin{tabular}{|c|c|c|c|}
\hline Characteristics & $\begin{array}{c}\text { Generation X } \\
(1961-1980)\end{array}$ & $\begin{array}{l}\text { Generation } Y \\
(1981-1995)\end{array}$ & $\begin{array}{c}\text { Generation Z } \\
\text { (Born after 1995) }\end{array}$ \\
\hline Formative experiences & $\begin{array}{l}\text { End of Cold War } \\
\text { Fall of Berlin Wall } \\
\text { Reagan / Corbachev } \\
\text { Thatcherism } \\
\text { Live Aid } \\
\text { Introduction of first PC } \\
\text { Early mobile technology } \\
\text { Latch-key kids; } \\
\text { rising levels of divorce }\end{array}$ & $\begin{array}{l}\text { 9/11 terrorist attacks } \\
\text { Playstation } \\
\text { Social media } \\
\text { Invasion of Iraq } \\
\text { Reaily TV } \\
\text { Coogle Earth } \\
\text { Clastonbury }\end{array}$ & $\begin{array}{l}\text { Economic downtum } \\
\text { Clobal warming } \\
\text { Clobal focus } \\
\text { Mobile devices } \\
\text { Energy crisis } \\
\text { Arab Spring } \\
\text { Produce own media } \\
\text { Cloud computing } \\
\text { Wiki-leaks }\end{array}$ \\
\hline $\begin{array}{l}\text { Percentage in } \\
\text { U.K. workforce }\end{array}$ & & & $\begin{array}{l}\text { Currently employed in } \\
\text { either part-time jobs or } \\
\text { new apprenticeships }\end{array}$ \\
\hline Aspiration & Work-life balance & $\begin{array}{l}\text { Freedom } \\
\text { and flexibility }\end{array}$ & $\begin{array}{l}\text { Security } \\
\text { and stability }\end{array}$ \\
\hline $\begin{array}{l}\text { Attitude toward } \\
\text { technology }\end{array}$ & Digital Immigrants & Digital Natives & $\begin{array}{l}\text { "Technoholics"- entirely dependent } \\
\text { on I; limited grasp of alternatives }\end{array}$ \\
\hline $\begin{array}{l}\text { Attitude toward } \\
\text { career }\end{array}$ & $\begin{array}{l}\text { Early "portfolio" careers } \\
\text { - loyal to profession, not } \\
\text { necessarily to employer }\end{array}$ & $\begin{array}{c}\text { Digital entrepreneurs - } \\
\text { work "with" organisations } \\
\text { not "for" }\end{array}$ & $\begin{array}{l}\text { Career multitaskers - will move } \\
\text { seamlessly between organisations } \\
\text { and "pop-up" businesses }\end{array}$ \\
\hline Signature product & Personal Computer & $\square$ Tablet/Smart Phone & $\begin{array}{l}\text { Coogle glass, graphene, } \\
\text { nano-computing. } \\
\text { 3-D printing. driverless cars }\end{array}$ \\
\hline Communication media & E-mail and text message & Text or social media & $\begin{array}{l}\text { Hand-held (or integrated into } \\
\text { clothing) communication devices }\end{array}$ \\
\hline $\begin{array}{l}\text { Communication } \\
\text { preference }\end{array}$ & $\begin{array}{l}\text { Text messaging or e-mail } \\
\text { TMS }\end{array}$ & $\begin{array}{l}\text { Online and mobile } \\
\text { (text messaging) }\end{array}$ & Facetime \\
\hline $\begin{array}{l}\text { Preference when making } \\
\text { financial decisions }\end{array}$ & $\begin{array}{l}\text { Online - would prefer } \\
\text { face-to-face if time permitting }\end{array}$ & Face-to-face & $\begin{array}{l}\text { Solutions will be digitally } \\
\text { crowd-sourced }\end{array}$ \\
\hline
\end{tabular}

Figure 2. Generation Categorization Images: Characteristic Difference By Year of Birth (Source: https://parent.binus.ac.id/)

Table 1. Informant profile Generation X, Y, Z

\begin{tabular}{|c|c|c|c|c|c|}
\hline \multicolumn{6}{|c|}{ Here's the informant's profile: } \\
\hline \multicolumn{2}{|c|}{ Informant 1} & \multicolumn{2}{|c|}{ Informant 2} & \multicolumn{2}{|c|}{ Informant 3} \\
\hline Name & : Sylvania Devi Noviana & Name & : Sicilia Devi Verdiani & Name & : Febryna \\
\hline Role & : Generation X & Role & : Generation Y & Role & : Generation Z \\
\hline Reason & : Born in 1980 & Reason & : Born in 1983 & Reason & : Born in 2000 \\
\hline
\end{tabular}

The study used two data collection techniques: ethnographic methods and source interviews that represent each generation of LINE app users. At the level of secondary data collection data collection is done with interview 
techniques interview results that have been done and existing documents, the results of data analysis conducted based on data analysis techniques Model Miles and Huberman where the data is reduced in accordance with the research problem, then compiled according to the pattern (data display) and drawn conclusions (verification).

The study used virtual ethnography on communication between personas on the LINE instant text platform to specifically observe the use of stickers as visual communication of images in conversations. Ethnography is typical research involving ethnographers to participate as observers, either overtly or covertly to observe what is happening in people's daily lives (Bate, 1997).

LINE has its own cartoon characters that are unique to LINE, there are Brown, Cony, Moon and James. In this study the focus of the discussion is the Virtual Ethnographic Study of LINE application users. Ethnographic model is a qualitative research model that has the aim of describing cultural characteristics contained in individuals or groups of people who are members of a group of cultural societies. Ethnographic researchers aim to interpret both open and gray manifestations of a culture.

In its development, the field of ethnographic practice undergoes increasingly clear changes. Ethnography is not sufficiently defined as just a method or technique of data collection. Not just as a discipline of research based on culture, but as a combination of organizing concepts between observation and interview techniques to record the dynamics of people's behavior (Mariampolski, 1999).

It is therefore understandable that ethnography has the ability to explore in digital relationships. Ethnography on the internet as a new qualitative research method by adapting some features to traditional ethnography to study cultural culture and cultural practices that arise in text-based communication through computer media (Kozinets, 2009).

Ethnography on the internet involves a willingness to observe how communication between personas is built in cyberspace and how emotional expression is carried out there. As depicted in the following screenshot:

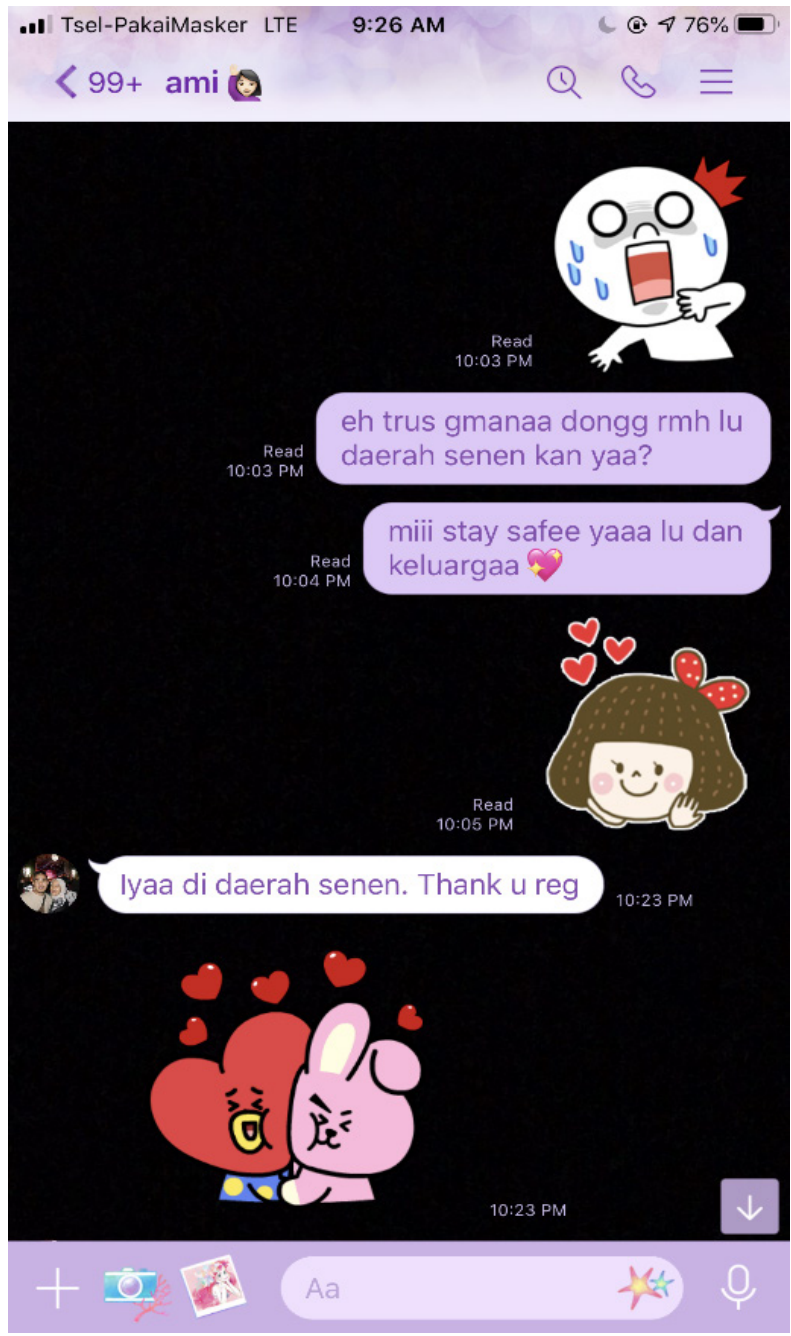

Figure 3. LINE LOVE Sticker Image 
From the image recorded the conversation of two LINE users who conducted Communication Between Personas with the topic of the pandemic covid 19 situation. User 1 and user 2 showed each other feelings of empathy related to the topic discussed. Feelings of pleasure, affection is represented by the image of a cheerful girl figure and a picture of a lot of hearts.

Where the heart in ancient Egyptian myths called the symbol used to symbolize the heart, the most important part of man, implying emotion, affection, or something like that. The user is Generation $\mathrm{Z}$ which is referred to as the Internet Generation. Since childhood familiar with digital communication loaded with emblem communication.

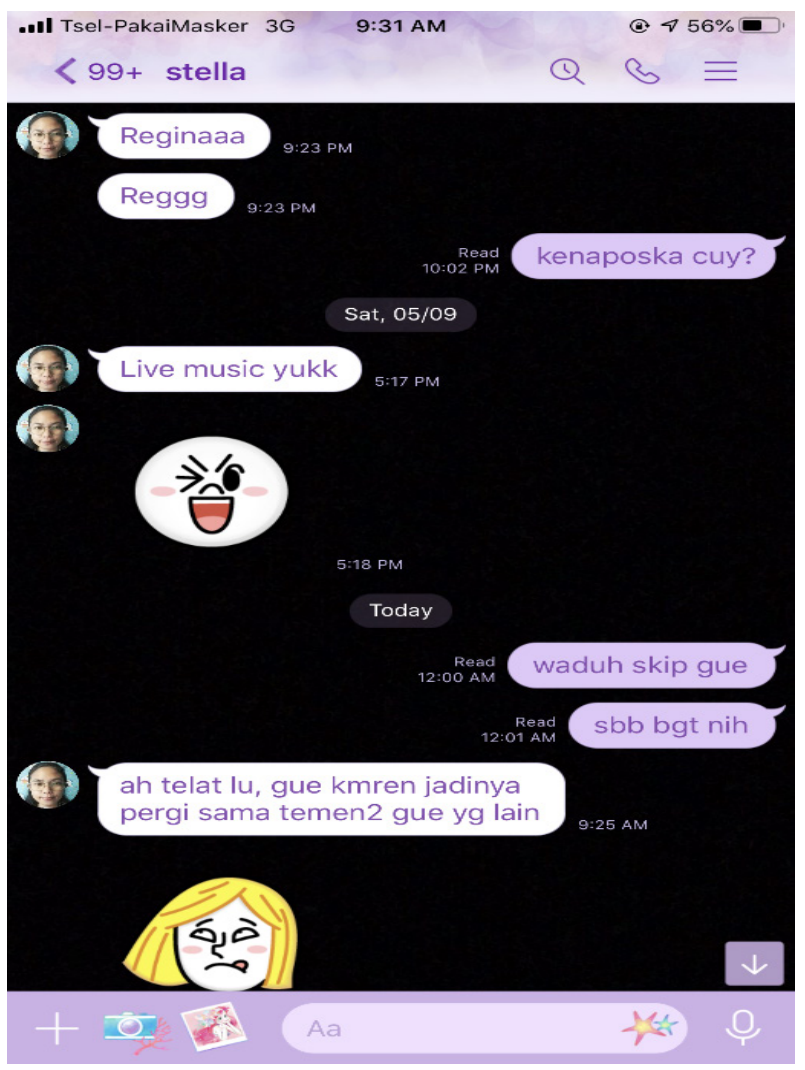

Figure 4. Sticker Image LINE DISAPPOINTED

In the picture, user 1 greets user 2 to invite you to enjoy live music online. Stickers used are emojis that represent enthusiasm to do activities together according to their favorites. The "wink" emoji represents a feeling of enthusiasm, passion and excitement. But in the screenshot, user 2 only replied the next day, and user 1 sent a short message of disappointment and added it with a sticker representing disappointment (a crumpled face).

From the two screenshots above confirms that the LINE text application provides more text-based communication facilities through stickers - stickers of its own cartoon characters that are unique to LINE. From ethnographic studies conducted in the LINE text application it can be known that in general the use of LINE applications have cultural characteristics in themselves as members of a group - in this case users of the LINE application as a free instant messaging application that can be used on various platforms such as smartphones, tablets, and computers.

Communication on social media has the characteristic of participation, that social media encourages feedback contributions from everyone who is interested and gives the community the opportunity to be able to communicate effectively according to their goals. Meet the emotional message needs of the communication actor in the process. Line's text platform has an exciting way to describe the emotions of these communication actors. Sticker facilities that make LINE different from other chat applications and become the flagship and uniqueness of LINE. Emoticons provided by LINE are also unusual, not just yellow emoticons that are often found in other chat applications. As revealed by the source of the LINE application users as follows. 
- Tell me about your experience communicating using LINE?

LINE is fun to communicate because it is easy to use and can be more expressive with the presence of stickers that vary.

- Explain why you use LINE stickers in communication?

To further animate communication, so that even through text, people who read it like talking directly to the other person

- How far does the sticker represent in communication?

Very influential, because it further revives the atmosphere of communication

- More often use stickers like what and explain why?

Less know the types of stickers in LINE. However, broadly speaking, it is more interested to use stickers that use words / sentences that can represent common answers to reply to messages.

\section{Source 2: MOTHER RT born in 1980, Generation Y}

- Tell me about your experience communicating using LINE?

Only occasionally use the LINE platform in online communication, but LINE still has its own attraction with the facilities of various stickers that are quite interesting.

- Explain why you use LINE stickers in communication?

Saves time and makes it easier to reply to incoming short messages.

- How far does the sticker represent in communication?

For use in informal communication, the presence of LINE stickers can simply represent the message you want to convey without the need to use long sentences.

- More often use stickers like what and explain why?

Funny, interactive and entertaining

\section{Source 3: Student born in 2000, Generation X}

- Tell me about your experience communicating using LINE?

My experience communicating using LINE is more exciting than any other chat app. Because there are interesting features such as stickers, timeline to nearby to make new friends.

- Explain why you use LINE stickers in communication?

Because the sticker is funny and represents expression when communicating without face to face.

- How far does the sticker represent in communication?

Quite representative, because some stickers show facial expressions that match what I want to convey.

- More often use stickers like what and explain why?

Stickers showing daily activities (watching tv, eating, bathing, working) or expressions of emotion (smile, sadness, anger). The reason is because the sticker is in accordance with what I want to convey.

Thus it can be concluded that computer mediated communication (computer mediated) technology in general provides convenience to communication actors. And in the level of nonverbal communication with symbols, LINE stickers and emoticons are a visualizing feature of various kinds of expression with a variety of fun characters, can be used as a substitute for nonverbal messages that do not appear in online communication.

The use of emoticons in communication that runs through instant messaging, can speed up the communication process, make communication more enjoyable and make it easier to express emotions and the occurrence of increased wealth of information so as to increase the efficiency and effectiveness of communication. 


\section{CONCLUSIONS}

The study used virtual ethnography on communication between personas on the LINE instant text platform to specifically observe the use of stickers as visual communication of images in conversations. Ethnography is typical research involving ethnographers to participate as observers, either overtly or covertly to observe what is happening in people's daily lives (Bate, 1997).

From ethnographic studies conducted in the LINE text application it can be known that in general the use of LINE applications have cultural characteristics in themselves as members of a group - in this case users of the LINE application as a free instant messaging application that can be used on various platforms such as smartphones, tablets, and computers. Communication on social media has the characteristic of participation, that social media encourages feedback contributions from everyone who is interested and gives the community the opportunity to be able to communicate effectively according to their goals.

Meet the emotional message needs of the communication actor in the process. Line's text platform has an exciting way to describe the emotions of these communication actors. Sticker facilities that make LINE different from other chat applications and become the flagship and uniqueness of LINE. Emoticons provided by LINE are also unusual, not just yellow emoticons that are often found in other chat applications.

Thus it can be concluded that computer mediated communication (computer mediated) technology in general provides convenience to communication actors. And in the level of nonverbal communication with symbols, LINE stickers and emoticons are a visualizing feature of various kinds of expression with a variety of fun characters, can be used as a substitute for nonverbal messages that do not appear in online communication.

The use of emoticons in communication that runs through instant messaging, can speed up the communication process, make communication more enjoyable and make it easier to express emotions and the occurrence of increased wealth of information so as to increase the efficiency and effectiveness of communication.

\section{REFERENCE}

Ardianto, Elvinaro. (2011). Metodologi Penelitian untuk Public Relations Kuantitatif dan Kualitatif. Bandung: Simbiosa Rekatama Media.

A.J.A.M. Van Deursen, J.A.G.M. Van Dijk. (2009) Using the Internet: skill related problems in users' online behavior. IWC 21.

Atkinson, Paul dan Hammersley, Martyn. (2009). Etnografi dan Observasi Partisipan. Dalam Norman K Denzin dan Yvonna S. Linclon (eds.). Handbook of Qualitative Research, terjemahan Daryatno dkk, Yogyakarta: Pustaka Pelajar

Bate, S. P. (1997) "Whatever Happened to Organizational Anthropology? A Review of the Field of Organizational Ethnography and Anthropological Studies," Human Relations, 50(9), pp. 1147-1175. doi: $10.1177 / 001872679705000905$.

Berger, Artur Asa (2004) Tanda-Tanda Dalam Kebudayaan Kontemporer, trans. M. Dwi Mariyanto and Sunarto, Yogyakarta: Tiara Wacana.

Creswell John, W. (2016). Research Design: Pendekatan Metode Kualitatif, Kuantitatif, dan Campuran. Edisi Empat. Yogyakarta: Pustaka Pelajar.

Derks, D., Agneta H. Fishcer., Arjan E.R. Bos. (2007). The role of emoticon in computer- mediated communication: A review. Computers in human behavior, doi: 10.1016/j.chb.2007.04.004.

Devito, J. (1997). Komunikasi Antarpribadi, Edisi Kelima. Jakarta: Profesional Book.

Devito, Joseph. A. (2001). The Interpersonal Communication Book, Ninth Edition. NYC: Longman.

Ezumah, Bellarmine A. (2013). "College Students"' Use of Social Media: Site Preferences, Uses and Gratifications Theory Revisited”, International Journal of Business and Social Science, Vol. 4 No. 5; May 2013, pp. 27-34 
Fitrianur, I. (2016). Analisis Efek Penggunaan Media Sosial Line Messenger Pada Remaja di SMKN 1 Samarinda. eJournal Ilmu Komunikasi, 4(4), 240-253.

Flew, Terry. (2005). New Media, An Introduction, second edition. Australia: Oxford University Press.

Hachten, William A. (1981). The World News Prism: Changing Media, Clashing Ideologies, 2nd edition. United State of America: Iowa State University Press.

Herdiansyah, H. (2010). Metodologi Penelitian Kualitatif; Untuk Ilmuilmu Sosial. Jakarta: Salemba Humanika.

Hine, C. (2000). Virtual Etnography. London: SAGE Publications Inc.

Kriyantono, Rahmat. (2006). Teknik Praktis Riset Komunikasi. Jakarta: Kencana.

Kaplan, A. M., \& Haenlein, M. (2010). Users Of The World, Unite! The Challenges and Opportunities Of Social Media. Business Horizons, 53(1), 59-68. https://doi.org/10.1016/j.bushor.2009.09.003.

Kominfo.go.id (2014). Riset Kominfo dan UNICEF Mengenai Perilaku Anak dan Remaja Dalam Menggunakan Internet. SiaranPers No.17/PIH/Kominfo/2014. Diakses Tanggal 25 Februari 2017 pukul 23.09.

Kozinets, R. V. (2009). Netnography: Doing Ethnographic Research Online. 1st ed. London: Sage Publications Ltd.

Ikrawansyah, R. (2015). Pengaruh Motif Penggunaan Aplikasi Line Terhadap Kepuasan Pengguna Pada Mahasiswa Jurusan Ilmu Komunikasi di Kota Pekanbaru. Jom Fisip, 2(2),1-13.

Li, Charlene. (2010). Open Leadership, how social technology can transform the way you lead, Jossey-Bass, A Wiley Imprint, San Francisco.

Little John, S.W. (1989). Theories of Human Communication, Thrid Edition. Belmont, California: Wadsworth Publishing Company

Lowery, Shearon A dan DeFleur, Melvin L. (1995). Milestones in Mass Communication Research: Media Effect, third edition, New York: Longman Publishers USA

Luthfi, M. (2012). Pengaruh Media Sosial Line Terhadap Kebutuhan Afiliasi (Studi Korelasional tentang pengaruh media sosial Line terhadap kebutuhan afiliasi di kalangan mahasiswa komunikasi FISIP USU angkatan 2010-2012). Fakultas Komunikasi FISIP.

Marshall, C., Rossman, G. B. (2011). Primary Data Collection Methods Designing Qualitative Research. Los Angeles, CA: SAGE.

Mariampolski, H. (1999) “The Power of Ethnography,” International Journal of Market Research, 41(1), p. 12.

McQuail, D. (1987). Mass Communication Theory: An Introduction. Beverly Hills, California: Sage Publication.

McQuail, Denis \& Windahl, Sven. (1993). Communication Models, second edition. London \& New York: Longman.

Metronews.com. (2018). Indonesia Duduki Posisi Kedua Pengguna Line Terbesar dengan 30 Juta Pengguna. https://dailysocial.id/post/indonesia-duduki-posisi-kedua-penggunaline-terbesar-dengan-30-juta- pengguna. Diakses tanggal 14 Maret 2018 pukul 15.47.

Metronews.com. (2018). 130 Juta Penduduk Indonesia Sudah Pakai Medos. https://m.metrotvnews.com/teknologi/news-teknologi/0k8L1edk-130-juta-pendudukindonesia-sudah-pakai-medsos. Diakses Tanggal 17 Oktober 2018 pukul 02.06.

Miles, M.B \& Huberman A.M. (1984). Analisis Data Kualitatif. Terjemahan oleh Tjetjep Rohendi Rohidi. Jakarta: Penerbit Universitas Indonesia.

Moleong, Lexy J. (2006). Metode Penelitian Kualitatif. Bandung: Remaja Rosdakarya.

Morissan, Andy Corry Wardhani (2009). Teori Komunikasi. Bogor: PT. Gahlia Indonesia.

Mulyana, D. (2010). Metode Penelitian Komunikasi. Bandung: Rosdakarya.

Mulyana, D. (2016). Ilmu Komunikasi: Suatu Pengantar. Bandung: PT. Remaja Rosdakarya

Nasrullah, R. (2014). Teori dan Riset Media Siber (Cybermedia). Jakarta: Kencana. 
Nasrullah, Rulli. (2015). Media Sosial Perspektif Komunikasi, Budaya dan Sosioteknologi. Bandung: Simbiosa Rekatama Media.

Pavlik, John V. (1996). New Media Technology, Cultural and Commercial Perspectives. USA: Allyn and Bacon.

Pearson, Judy C. (1983). Interpersonal communication: clarity, confidence \& concern. Illionis: Scott, Foresmand \& Company.

Sugiyono. (2014). Metode Penelitian Kuantitatif, Kualitatif, dan R\&D. Cetakan ke-8. Bandung: ALFABETA, CV.

Sedarmayanti \& Hidayat, S. (2011). Metodologi Penelitian. Bandung: Mandar Maju.

Sendjaja, Sasa Djuarsa dkk. (1993). Pengantar Komunikasi. Jakarta: Universitas Terbuka

Shoemaker, Pamela J. \& Reese, Stephen D. (1996). Mediating the Message: Theories of Influences on Mass Media Content. Second Edition. New York: Longman

Sharf, B. F. (1999) "Beyond Netiquette: The Ethics of Doing Naturalistic Discourse Research on the Internet," in Jones, S. (ed.) Doing Internet Research: Critical Issues and Methods for Examining the Net. 2455 Teller Road, Thousand Oaks California 91320 United States: SAGE Publications, Inc., pp. 243-256. doi: 10.4135/9781452231471.n12.

Spradley, James P. (1997). Metode Etnografi. Yogyakarta: PT Tiara Wacana

Treem, J. W., \& Leonardi, P. M. (2012). Social Media Use in Organizations: Exploring the Affordances of Visibility, Editability, Persistence, and Association. Communication Yearbook, 36, 143-189.

Utami, A. M. V., Lestari, M. T., \& Putra, A. (2015). Communication Culture Change In New Media Era (Virtual Etnhography Studies about Usage of Line By Digital Natives). EProceeding of Management, 2(3), 4042-4050.

West, R. \& Turner, L. H. (2007). Pengantar Teori Komunikasi. Jakarta: Salemba Humanika.

Wiryanto. (2005). Pengantar Ilmu Komunikasi. Jakarta: Gramedia Widiasarana Indonesia.

Wood, Julia T. (2016). Interpersonal Communication: Everyday Encounters Eight Ed. Canada: Cengage Learning. 